\title{
COMPARISON OF SWALLOWING IN DIFFERENT TYPES OF PARTIAL LARYNGECTOMIES
}

\author{
FARKLI PARSIYEL LARENJEKTOMI TEKNIKLERINDE YUTMANIN KARŞILAŞTIRILMASI
}

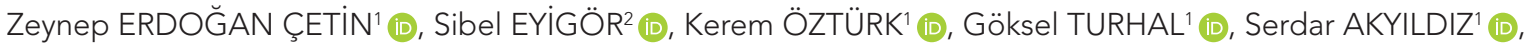 \\ Atilla YAVUZER ${ }^{1}$
}

${ }^{1}$ Ege University, School of Medicine, Department of Otolaryngology, Izmir, Turkey
${ }^{2}$ Ege University, School of Medicine, Department of Physical Therapy and Rehabilitation, Izmir, Turkey

ORCID IDs of the authors: Z.E.Ç. 0000-0003-1213-4033; S.E. 0000-0002-9781-2712; K.Ö. 0000-0003-2754-4166; G.T. 0000-0003-0020-1921; S.A. 0000-0001-9539-3916; A.Y. 0000-0002-8446-8721

Cite this article as: Cetin ZE, Eyigor S, Ozturk K, Turhal G, Akyildiz S, Yavuzer A. Comparison of swallowing in different types of partial laryngectomies. J Ist Faculty Med 2021;84(4):502-7. doi: 10.26650/IUITFD.2021.839817

\section{ABSTRACT}

Objective: We designed this study to assess and compare the effects of different partial laryngectomy (PL) techniques on swallowing.

Material and Methods: Ten patients had laryngofissure with cordectomy, ten had frontal anterior laryngectomy with epiglottic reconstruction (FAL), ten had frontolateral laryngectomy (FLL), ten had cricohyoidopexy (CHP), ten had cricohyoidoepiglottopexy (CHEP), and ten had supraglotic laryngectomy. Swallowing was assessed with flexible endoscopy.

Results: Mild or moderate dysphagia for solid foods was discovered significantly more often in CHP patients compared to FLL and FAL $(p<0.05)$ patients. Dysphagia discoveries for semi-solid and liquid food didn't significantly differ among PL's ( $p>0.05)$. Compared to other PLs, the penetration-aspiration test with 10 $\mathrm{ml}$ of water was distinctly lower in cordectomy and FLL patients $(\mathrm{p}<0.05)$.

Conclusion: Penetration and aspiration with $10 \mathrm{ml}$ of water was marked lower in cordectomy and FLL patients matched to other PL patients. With studies involving more patients, it will be possible to increase the evidence value of our results.

Keywords: Partial laryngectomy, fiberoptic endoscopic evaluation of swallowing (FEES), deglutition disorders, dysphagia

\section{ÖZET}

Amaç: Bu çalışma, farklı parsiyel larenjektomi (PL) tekniklerinin yutma üzerindeki etkilerini değerlendirmek ve karşılaştırmak amacıyla tasarlandı.

Gereç ve Yöntemler: On hastada kordektomi ile laringofissür, onunda epiglotik rekonstrüksiyon (FAL) ile frontal anterior larenjektomi, on hastada frontolateral larenjektomi (FLL), on hastada krikohiyoidopeksi (CHP), on hastada krikohiyoidoepiglottopeksi (CHEP) ve diğer onunda supraglotik larenjektomi operasyonu yapılmıştı. Yutma fleksible endoskopi ile değerlendirildi.

Bulgular: Katı yiyecekler için hafif veya orta derecede disfaji, CHP hastalarında FLL ve FAL hastalarına kıyasla anlamlı olarak daha sık olduğu bulundu $(p<0,05)$. Yarı katı ve sıvı gıdalar için disfaji araştırmasında, PL'ler arasında önemli ölçüde farklılık gösterilmedi ( $p>0,05)$. Diğer PL'lere kıyasla, $10 \mathrm{ml}$ su ile penetrasyon-aspirasyon testi, kordektomi ve FLL hastalarında belirgin şekilde daha düşüktü $(p<0,05)$.

Sonuç: Kordektomi ve FLL hastalarında diğer PL hastalarına göre $10 \mathrm{ml}$ su ile penetrasyon ve aspirasyon testi, daha düşüktü. Daha fazla hastayı içeren çalışmalar sayesinde vermiş olduğumuz sonuçların kanıt değerinin artırılması mümkün olacaktır.

Anahtar Kelimeler: Parsiyel larenjektomi, fiberoptik endoskopik yutma değerlendirmesi (FEYD), yutma bozuklukları, disfaji

* This manuscript was presented in $36^{\text {th }}$ Turkish National Otorhinolaryngology and Head \& Neck Surgery Congress.

Corresponding author/iletişim kurulacak yazar: zeynep_erd@yahoo.com

Submitted/Başvuru: 14.12.2020 • Revision Requested/Revizyon Talebi: $06.01 .2021 \bullet$

Last Revision Received/Son Revizyon: 26.04.2021 • Accepted/Kabul: 06.05.2021 • Published Online/Online Yayın: 20.09 .2021 


\section{INTRODUCTION}

Laryngeal cancer is the most common malignancy of head and neck cancer in terms of frequency (1). Partial laryngectomy $(\mathrm{PL})$ is indicated in the early stages and in some of the advanced stages of laryngeal cancer. PL has the advantage of preserving laryngeal functions, having lower morbidity, and increasing quality of life. However, swallowing dysfunction following $\mathrm{PL}$ is an important issue in some patients and may require a considerable amount of care and rehabilitation (2). The evaluation and treatment plan for swallowing difficulties has to be completed as soon as possible (3). Swallowing function, physiology, and aspiration can be effectively evaluated with fiberoptic endoscopic evaluation of swallowing (FEES). By assessing swallowing functions and implementing rehabilitation plans, patients could start a normal diet and potential complications such chronic aspiration, malnutrition, and dehydration could be prevented (3).

Objective evaluation and comparison of the effects of different $\mathrm{PL}$ techniques on swallowing functions is the purpose of this study.

\section{MATERIAL AND METHODS}

This study was done between July 2012 and February 2013. Sixty patients operated for laryngeal carcinoma were included in the study. Ten had laryngofissure with cordectomy, ten had frontal anterior laryngectomy with epiglottic reconstruction ( $F A L)$, ten had frontolateral laryngectomy (FLL), ten had cricohyoidopexy (CHP), ten had cricohyoidoepiglottopexy (CHEP) and ten had supraglottic laryngectomy. All of the patients were informed about the study and their informed consent was gained. This research was submitted to the Institutional Review Board and approved (Date: 14.09.2012, No: 12-7/80). Our study was completed within the framework of international ethical standards and the World Health Organization Helsinki Declaration.

\section{Patient selection}

Sixty patients, who underwent PL at least six months ago for histopathologically proven laryngeal cancer, were included in the study. Patients having symptoms of aspiration (coughing) and swallowing difficulties (dysphagia) were included. Patients with tumor recurrence, previous radiotherapy, and head and neck surgery other than $\mathrm{PL}$ were excluded from the study.

\section{Instrumentation}

Sociodemographic data was collected from patient records. Endoscopic assessment was carried out in an upright-seated position without using topical anesthesia to the nasal cavity. A video was recorded for each individual patient. We used a flexible nasopharyngoscope camera (KAY PENTAX Ltd, Montvale, NJ, USA) during the procedures.

\section{Procedure}

The test procedure comprised two administrations of 3 $\mathrm{ml}, 5 \mathrm{ml}$, and $10 \mathrm{ml}$ of water stained with food dye (green) via an injector. Likewise, swallowing tests were completed with two administrations of one dessert spoonful of yoghurt $(5 \mathrm{ml})$ colored with food dye and fish crackers. Premature spillage, retention-pooling, penetration, aspiration and reflex coughing were scored (from 1 to 5) with the scoring system established by Topaloglu et al. (Table 1) (4). An otolaryngologist and a physical therapy and rehabilitation specialist were present for the duration of each procedure and all procedures were video-recorded. As in our previously published study in different patient groups, the total test results were blindly evaluated by the same physician and unchanged otolaryngologist, who were focused and specialized in this field, regardless of the treatment procedures (5).

\section{Statistical analysis}

Computer software (SPSS version 22.0, SPSS Inc. Chicago, IL, USA) was conducted for statistical analysis. Comparison of categorical data was made with chi-square $(X 2)$ exact tests. According to the distribution pattern of the data, Wilcoxon and Mann-Whitney $U$ tests were used in

Table 1: Swallowing grading scale developed by Topaloglu et al.

\begin{tabular}{|c|c|c|c|}
\hline$\stackrel{n}{\stackrel{n}{c}}$ & 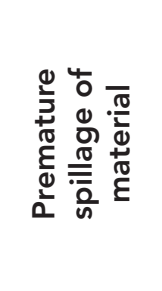 & 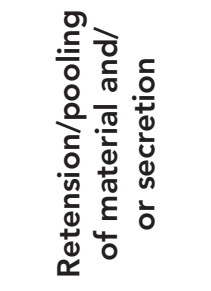 & 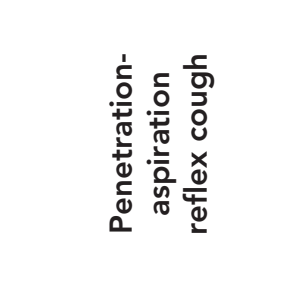 \\
\hline 1 & Severe & $\begin{array}{l}\text { Severe } \\
\text { retention/ } \\
\text { pooling }\end{array}$ & $\begin{array}{l}\text { Enterance of mate- } \\
\text { rial into trachea; no } \\
\text { reflex cough }\end{array}$ \\
\hline 2 & Marked & $\begin{array}{l}\text { Marked } \\
\text { retention/ } \\
\text { pooling }\end{array}$ & $\begin{array}{l}\text { Enterance of material } \\
\text { into trachea; with } \\
\text { reflex cough }\end{array}$ \\
\hline 3 & Moderate & $\begin{array}{l}\text { Mild } \\
\text { retention/ } \\
\text { pooling }\end{array}$ & $\begin{array}{l}\text { Enterance of material } \\
\text { into larynx; remaining } \\
\text { above the trachea no } \\
\text { reflex cough }\end{array}$ \\
\hline 4 & Mild & $\begin{array}{l}\text { Coating } \\
\text { residue/ } \\
\text { secretion }\end{array}$ & $\begin{array}{l}\text { Enterance of ma- } \\
\text { terial into larynx; } \\
\text { remaining above the } \\
\text { trachea with reflex } \\
\text { cough forming }\end{array}$ \\
\hline 5 & None & $\begin{array}{l}\text { No retention/ } \\
\text { pooling }\end{array}$ & $\begin{array}{c}\text { No enterance of } \\
\text { material into larynx } \\
\text { or trachea; no reflex } \\
\text { cough }\end{array}$ \\
\hline
\end{tabular}


the analysis of nonparametric variables, and independent, and paired sample t-tests were used in the analysis of parametric variables. Determining the distribution pattern of the data was provided by the Shapiro-Wilk test. The distribution of the groups in our study was non-parametric. Considering the distribution of the data, Pearson or Spearman correlation analysis was used. Data was expressed as "median, interquartile range (IQR)". A p value of $<0.05$ was considered statistically significant.

\section{RESULTS}

Sixty patients treated with PL were involved in the study. Five $(8.3 \%)$ of the patients were female and 55 (91.7\%) were male, with a mean age of $59.87 \pm 7.93$ years (range 33-79 years).

Forty-four (73.3\%) patients reported coughing, two (3.3\%) reported coughing and dysphagia, and 14 (23.3\%) reported only dysphagia. The type of PL present in the patient and their symptoms were not statistically correlated ( $p>0.05)$. The presence and frequency of the subjective symptoms (difficulty in bolus control, need to clear throat, food gets stuck, choking) are presented in Table 2. Subjective symptoms and the type of PL were not statistically correlated ( $p>0.05)$.
Dysphagia for solid, semi-solid, and liquid food was evaluated and the data (according to the types of PL) is presented in Table 3. Mild or moderate dysphagia for solid foods was significantly more prevalent in CHP patients compared to FLL and FAL $(p<0.05)$ patients. Dysphagia for semi-solid and liquid food did not significantly differ among different PL's ( $p>0.05)$.

Premature spillage, residue-secretion, and penetration-aspiration scores were evaluated with fiberoptic endoscopy. Scores for different types of PL are presented in Table 4. Penetration-aspiration with $10 \mathrm{ml}$ water was meaningfully lower in cordectomy and FLL patients compared to supraglottic laryngectomy, CHP and CHEP patients $(p<0.05)$. Other scores had no significant difference among the groups (Table 4) ( $p>0.05)$.

\section{DISCUSSION}

There are many reports assessing the swallowing function in a certain type of PL (6-12). While some researchers evaluated swallowing function with N/G tube removal time or gastrostomy tube removal rates in previous reports, others used quality of life measures $(9,12-15)$. Videofluoroscopy is also a widely used technique for the evaluation of swallowing $(7,8,12,16)$. However, a study,

Table 2: Operation types and subjective complaints

\begin{tabular}{|c|c|c|c|c|c|c|c|c|}
\hline \multirow[b]{2}{*}{ Complaint } & & \multicolumn{7}{|c|}{ Operation type } \\
\hline & & $\begin{array}{l}\text { Supraglottic } \\
\text { laryngectomy }\end{array}$ & Cordectomy & $\mathrm{CHP}$ & CHEP & FLL & FAL & $p$ \\
\hline Cough & N (\%) & 7 (70\%) & $8(80 \%)$ & $8(80 \%)$ & $8(80 \%)$ & 7 (70\%) & $6(60 \%)$ & $p>0.05$ \\
\hline $\begin{array}{l}\text { Cough, } \\
\text { dysphagia }\end{array}$ & N (\%) & $0(0 \%)$ & $0(0 \%)$ & $2(20 \%)$ & $0(0 \%)$ & $0(0 \%)$ & $0(0 \%)$ & \\
\hline Dysphagia & N (\%) & $3(30 \%)$ & $2(20 \%)$ & $0(0 \%)$ & $2(20 \%)$ & $3(30 \%)$ & $4(40 \%)$ & \\
\hline \multirow[t]{2}{*}{$\begin{array}{l}\text { Difficulty in } \\
\text { bolus control }\end{array}$} & $\begin{array}{l}\text { Not present } \\
(\mathrm{N} ; \%)\end{array}$ & $9(90 \%)$ & $9(90 \%)$ & $9(90 \%)$ & $8(80 \%)$ & 10 (100\%) & $10(100 \%)$ & $p>0.05$ \\
\hline & $\begin{array}{l}\text { Present } \\
(\mathrm{N} ; \%)\end{array}$ & $1(10 \%)$ & $1(10 \%)$ & $1(10 \%)$ & $2(20 \%)$ & $0(0 \%)$ & $0(0 \%)$ & \\
\hline \multirow[t]{2}{*}{$\begin{array}{l}\text { Need to clear } \\
\text { throat }\end{array}$} & $\begin{array}{c}\text { Not present } \\
(\mathrm{N} ; \%)\end{array}$ & $4(40 \%)$ & $7(70 \%)$ & $4(40 \%)$ & $8(80 \%)$ & 8 (80\%) & $7(70 \%)$ & $p>0.05$ \\
\hline & $\begin{array}{l}\text { Present } \\
(\mathrm{N} ; \%)\end{array}$ & $6(60 \%)$ & $3(30 \%)$ & $6(60 \%)$ & $2(20 \%)$ & $2(20 \%)$ & $3(30 \%)$ & \\
\hline \multirow{2}{*}{$\begin{array}{l}\text { Sensation of } \\
\text { a lump in the } \\
\text { throat }\end{array}$} & $\begin{array}{l}\text { Not present } \\
(\mathrm{N} ; \%)\end{array}$ & $6(60 \%)$ & $7(70 \%)$ & $5(50 \%)$ & $7(70 \%)$ & $6(60 \%)$ & $5(50 \%)$ & $p>0.05$ \\
\hline & $\begin{array}{l}\text { Present } \\
(\mathrm{N} ; \%)\end{array}$ & $4(40 \%)$ & $3(30 \%)$ & $5(50 \%)$ & $3(30 \%)$ & $4(40 \%)$ & $5(50 \%)$ & \\
\hline \multirow[t]{2}{*}{$\begin{array}{l}\text { Sense of } \\
\text { choking }\end{array}$} & $\begin{array}{c}\text { Not present } \\
(\mathrm{N} ; \%)\end{array}$ & 7 (70\%) & $8(80 \%)$ & $6(60 \%)$ & $9(90 \%)$ & $10(100 \%)$ & $10(100 \%)$ & $p>0.05$ \\
\hline & $\begin{array}{c}\text { Present } \\
(\mathrm{N} ; \%)\end{array}$ & $3(30 \%)$ & $2(20 \%)$ & 4 (40\%) & $1(10 \%)$ & $0(0 \%)$ & $0(\% 0)$ & \\
\hline
\end{tabular}

CHP: Cricohyoidopexy; CHEP: Cricohyoidoepiglottopexy; FLL: Frontolateral laryngectomy; FAL: Frontal anterior laryngectomy 
Table 3: Dysphagia table

\begin{tabular}{|c|c|c|c|c|c|c|c|c|c|}
\hline \multicolumn{3}{|c|}{ Operation type } & \multirow{2}{*}{$\begin{array}{c}\begin{array}{c}\text { Supraglottic } \\
\text { laryngectomy }\end{array} \\
8\end{array}$} & \multirow{2}{*}{$\frac{\text { Cordectomy }}{7}$} & \multirow{2}{*}{$\frac{\mathrm{CHP}}{5}$} & \multirow{2}{*}{$\begin{array}{c}\text { CHEP } \\
7\end{array}$} & \multirow{2}{*}{$\begin{array}{c}\text { FLL } \\
9\end{array}$} & \multirow{2}{*}{$\frac{\text { FAL }}{9}$} & \multirow{2}{*}{$\begin{array}{c}\text { Total } \\
45\end{array}$} \\
\hline Dysphagia & Not present & $\mathrm{n}$ & & & & & & & \\
\hline & & $\%$ & 80 & 70 & 50 & 70 & 90 & 90 & 75 \\
\hline & Mild or moderate & $\mathrm{n}$ & 2 & 3 & 2 & 3 & 1 & 1 & 12 \\
\hline & & $\%$ & 20 & 30 & 20 & 30 & 10 & 10 & 20 \\
\hline & Severe & $\mathrm{n}$ & 0 & 0 & 3 & 0 & 0 & 0 & 3 \\
\hline & & $\%$ & 0 & 0 & 30 & 0 & 0 & 0 & 5 \\
\hline & Total & $\mathrm{n}$ & 10 & 10 & 10 & 10 & 10 & 10 & 60 \\
\hline & & $\%$ & 100 & 100 & 100 & 100 & 100 & 100 & 100 \\
\hline \multirow{8}{*}{$\begin{array}{l}\text { Dysphagia } \\
\text { to semisolid } \\
\text { food }\end{array}$} & Not present & $\mathrm{n}$ & 6 & 8 & 6 & 8 & 10 & 9 & 47 \\
\hline & & $\%$ & 60 & 80 & 60 & 80 & 100 & 90 & 78.3 \\
\hline & Mild or moderate & $\mathrm{n}$ & 4 & 2 & 4 & 2 & 0 & 1 & 13 \\
\hline & & $\%$ & 40 & 20 & 40 & 20 & 0 & 10 & 21.7 \\
\hline & Severe & $\mathrm{n}$ & 0 & 0 & 0 & 0 & 0 & 0 & 0 \\
\hline & & $\%$ & 0 & 0 & 0 & 0 & 0 & 0 & 0 \\
\hline & Total & $\mathrm{n}$ & 10 & 10 & 10 & 10 & 10 & 10 & 60 \\
\hline & & $\%$ & 100 & 100 & 100 & 100 & 100 & 100 & 100 \\
\hline \multirow{8}{*}{$\begin{array}{l}\text { Dysphagia } \\
\text { to liquid } \\
\text { food }\end{array}$} & Not present & $\mathrm{n}$ & 5 & 10 & 8 & 4 & 8 & 8 & 43 \\
\hline & & $\%$ & 50 & 100 & 80 & 40 & 80 & 80 & 71.7 \\
\hline & Mild or moderate & $\mathrm{n}$ & 4 & 0 & 2 & 6 & 2 & 2 & 16 \\
\hline & & $\%$ & 40 & 0 & 20 & 60 & 20 & 20 & 26.7 \\
\hline & Severe & $\mathrm{n}$ & 1 & 0 & 0 & 0 & 0 & 0 & 1 \\
\hline & & $\%$ & 10 & 0 & 0 & 0 & 0 & 0 & 1.7 \\
\hline & Total & $\mathrm{n}$ & 10 & 10 & 10 & 10 & 10 & 10 & 60 \\
\hline & & $\%$ & 100 & 100 & 100 & 100 & 100 & 100 & 100 \\
\hline
\end{tabular}

CHP: Cricohyoidopexy; CHEP: Cricohyoidoepiglottopexy; FLL: Frontolateral laryngectomy; FAL: Frontal anterior laryngectomy

Table 4: $P$ values regarding different laryngectomy types and swallowing scores

\begin{tabular}{lccc}
\hline & $\begin{array}{c}\text { Premature } \\
\text { spillage }\end{array}$ & $\begin{array}{c}\text { Residue, } \\
\text { secretion }\end{array}$ & $\begin{array}{c}\text { Penetration, } \\
\text { aspiration, } \\
\text { reflex cough }\end{array}$ \\
\hline $3 \mathrm{ml}$ water & .539 & p value & p value \\
$5 \mathrm{ml}$ water & .490 & .471 & .097 \\
$10 \mathrm{ml}$ water & .305 & .614 & .163 \\
$5 \mathrm{ml}$ & .385 & .303 & .024 \\
yoghurt & & & .083 \\
$\begin{array}{l}\text { Fish } \\
\text { cracker }\end{array}$ & .540 & .314 & .066 \\
\hline
\end{tabular}

that compared swallowing functions in different types of PL with FEES, is missing. A study conducted by Alicandri-Ciufelli et al. compared swallowing functions of supraglottic laryngectomy and supracricoid partial laryngectomy (SCPL) patients with FEES (12). Other studies usually evaluated swallowing in only one type of $\mathrm{PL}$ or compared supracricoid laryngectomy with total laryngectomy $(12,16)$. Alicandri-Ciufelli et al. found no statistically significant difference between supraglottic laryngectomy and supracricoid laryngectomy patients regarding swallowing functions evaluated with FEES (12). They also evaluated cases with both preserved arytenoids, radiotherapy, different ages, and a different time interval after surgery, and it was concluded that only radiotherapy had a significant negative effect on supracricoid laryngectomy patients with FEES (4). Premature spillage, residue-se- 
cretion, and penetration-aspiration scores were higher in patients with both arytenoids preserved and in patients that did not receive radiotherapy, but this difference was not statistically significant (4). Because patients with a history of radiotherapy were excluded and both arytenoids were preserved in all patients, these were not evaluated in this study.

Another important step in preserving the swallowing function is to preserve the superior laryngeal nerve. If this nerve is damaged, the cricopharyngeal sphincter and the cough reflex will be negatively affected and the patient won't be able to recognize aspiration $(3,17,18)$. This may hamper subsequent swallowing rehabilitation and may extend adaptation time. All effort should be taken to preserve both superior laryngeal nerves in laryngeal conservation surgery.

Zacharek et al. evaluated the swallowing function of 10 supracricoid laryngectomy patients with FEES and modified barium swallow studies (19). They reported swallowing difficulties in all patients. Supraglottic sensory loss secondary to unilateral or bilateral damaged superior laryngeal nerve, changed base of tongue/vallecular anatomy after extraction of epiglottis, physiologic insufficiency of the neoglottal valve, or a combination of these three mechanisms were the proposed mechanisms for swallowing difficulties $(15,18)$. All of the patients in this study tolerated oral food intake and were decanulated. None of the patients developed aspiration pneumonia. These findings show that all patients should have a sufficient cough reflex to protect their lungs from aspiration pneumonia and an active tracheopulmonary mucociliary clearance system. In addition, these studies emphasize the importance of adequate respiratory function in patients undergoing SCPL. In a study evaluating the swallowing function of 116 SCPL patients, 45 patients that had aspiration in videofluoroscopic study were assessed with high-resolution computed tomography and no statistically noteworthy difference was established among these patients and control groups regarding the radiographic images (19).

This is the first research to compare swallowing functions of different types of PL with FEES. A limited number of patients and inadequate randomization are the limitations of this study. Objective evaluation of swallowing in PL patients provides valuable data and feedback for both the doctor and the patient.

\section{CONCLUSION}

In conclusion, penetration and aspiration with $10 \mathrm{ml}$ of water was meaningfully lower in cordectomy and FLL patients compared to supraglottic laryngectomy, CHP, and CHEP patients. This study is important because it is the first study, which evaluated swallowing objectively in patients who underwent six different PL. The most important result of this study, regardless of which PL technique is applied, is that aspiration problems are not caused, other than highvolume water ingestion, after the $6^{\text {th }}$ postoperative month in patients, who have preserved both arytenoids and have not applied radiotherapy. We think that we can reduce the concern of surgeons with this objective study about swallowing that will occur as a result of the PL technique preference. Further studies with larger patient groups are warranted to obtain more reliable results.

Informed Consent: Written consent was obtained from the participants.

Ethics Committee Approval: This study was approved by the Clinical Research Ethical Committee of the Ege University School of Medicine (Date: 14.09.2012, No: 12-7/80).

Peer Review: Externally peer-reviewed.

Author Contributions: Conception/Design of Study- A.K., K.A.D., G.Ü.; Data Acquisition- Z.E.Ç., G.T.; Data Analysis/Interpretation- Z.E.Ç.; Drafting Manuscript- Z.E.Ç., S.E., K.Ö.; Critical Revision of Manuscript- Z.E.Ç., S.E., A.Y.; Final Approval and Accountability- Z.E.Ç., S.E., K.Ö., G.T., S.A., A.Y.

Conflict of Interest: Authors declared no conflict of interest.

Financial Disclosure: Authors declared no financial support.

Bilgilendirilmiş Onam: Katılımcılardan bilgilendirilmiş onam alınmıştır.

Etik Komite Onayı: Bu çalışma için etik komite onayı Ege Üniversitesi Tıp Fakültesi Klinik Araştırmalar Etik Kurulu'ndan alınmıştır (Tarih: 14.09.2012, No: 12-7/80).

Hakem Değerlendirmesi: Dış bağımsız.

Yazar Katkıları: Çalışma Konsepti/Tasarım- A.K., K.A.D., G.Ü.; Veri Toplama- Z.E.Ç., G.T.; Veri Analizi/Yorumlama- Z.E.Ç.; Yazı TaslağıZ.E.Ç., S.E., K.Ö.; İçeriğin Eleştirel İncelemesi- Z.E.Ç., S.E., A.Y.; Son Onay ve Sorumluluk- Z.E.Ç., S.E., K.Ö., G.T., S.A., A.Y.

Çıkar Çatışması: Yazarlar çıkar çatışması beyan etmemişlerdir.

Finansal Destek: Yazarlar finansal destek beyan etmemişlerdir.

\section{REFERENCES}

1. Jemal A, Siegel R, Ward E, Murray $T, X u$ J, Thun MJ. Cancer statistics, 2007. CA Cancer J Clin 2007;57(1):43-66. [CrossRef]

2. Yücetürk AV, Günhan K. Supracricoid laryngectomy: oncological and functional outcome. Kulak Burun Bogaz Ihtis Der 2004;13(3-4):57-61.

3. Longeman JA. Mechanisms of normal and abnormal swallowing cummings Otolaryngology Head \& Neck Surgery Mosby Elsevier. $5^{\text {th }}$ Edition ed. PW F, editor. Philadelphia PA2010. [CrossRef] 
4. Topaloglul, KöprücüG, Bal M. Analysis of swallowing function after supracricoid laryngectomy with cricohyoidopexy. Otolaryngol Head Neck Surg 2012;146(3):412-8. [CrossRef]

5. Cetin ZE, Eyigor S, Ozturk K, Akagunduz O, Turhal G, Kirazli $T$, et al. Evaluation of the effect of various radiotherapy modalities on swallowing function in patients with nasopharyngeal cancer. Ear Nose Throat J 2019;98(9):56670. [CrossRef]

6. Rademaker AW, Logemann JA, Pauloski BR, Bowman JB, Lazarus $C L$, Sisson GA, et al. Recovery of postoperative swallowing in patients undergoing partial laryngectomy. Head Neck 1993;15(4):325-34. [CrossRef]

7. Woisard V, Puech M, Yardeni E, Serrano E, Pessey JJ. Deglutition after supracricoid laryngectomy: compensatory mechanisms and sequelae. Dysphagia 1996;11(4):265-9. [CrossRef]

8. Schweinfurth JM, Silver SM. Patterns of swallowing after supraglottic laryngectomy. Laryngoscope 2000;110(8):126670. [CrossRef]

9. Adamopoulos G, Yiotakis J, Stavroulaki P, Manolopoulos L. Modified supracricoid partial laryngectomy with cricohyoidopexy: series report and analysis of results. Otolaryngology Head Neck Surg 2000;123(3):288-93. [CrossRef]

10. Bron L, Pasche P, Brossard E, Monnier P, Schweizer V. Functional analysis after supracricoid partial laryngectomy with cricohyoidoepiglottopexy. Laryngoscope 2002;112(7 Pt 1):1289-93. [CrossRef]

11. Lima RA, Freitas EQ, Kligerman J, Dias FL, Barbosa MM, Sa GM, et al. Supracricoid laryngectomy with CHEP: functional results and outcome. Otolaryngology Head Neck Surg 2001;124(3):258-60. [CrossRef]
12. Alicandri-Ciufelli M, Piccinini A, Grammatica A, Chiesi A Bergamini G, Luppi MP, et al. Voice and swallowing after partial laryngectomy: factors influencing outcome. Head Neck 2013;35(2):214-9. [CrossRef]

13. Bron L, Brossard E, Monnier P, Pasche P. Supracricoid partial laryngectomy with cricohyoidoepiglottopexy and cricohyoidopexy for glottic and supraglottic carcinomas. Laryngoscope 2000;110(4):627-34. [CrossRef]

14. de Vincentiis M, Minni A, Gallo A, Di Nardo A. Supracricoid partial laryngectomies: oncologic and functional results. Head Neck 1998;20(6):504-9. [CrossRef]

15. Zacharek MA, Pasha R, Meleca RJ, Dworkin JP, Stachler RJ, Jacobs JR, et al. Functional outcomes after supracricoid laryngectomy. Laryngoscope 2001;111(9):1558-64. [CrossRef]

16. Dworkin JP, Meleca RJ, Zacharek MA, Stachler RJ, Pasha $\mathrm{R}$, Abkarian GG, et al. Voice and deglutition functions after the supracricoid and total laryngectomy procedures for advanced stage laryngeal carcinoma. Otolaryngology Head Neck Surg 2003;129(4):311-20. [CrossRef]

17. Longeman J. Evaluation and treatment of swallowing disorders, Austin, TX, Pro-Ed,. $2^{\text {nd }}$ ed1998.

18. Tucker HM. Deglutition following partial laryngectomy. In: Silver CE, ed. Laryngeal Cancer. Thieme,. New York1991.

19. Simonelli M, Ruoppolo G, de Vincentiis M, Di Mario M, Calcagno P, Vitiello $C$, et al. Swallowing ability and chronic aspiration after supracricoid partial laryngectomy. Otolaryngology Head Neck Surg 2010;142(6):873-8. [CrossRef] 